\title{
Pengaruh Komunikasi Dan Beban Kerja Terhadap Kinerja Pegawai Melalui Kepuasan Kerja Pegawai Pada Kantor Dewan Perwakilan Rakyat Daerah Provinsi Sumatera Utara
}

\author{
Lailan Musfiroh Hasibuan \\ Universitas Muhammadiyah Sumatera Utara Medan, Indonesia

\section{Sjahril Effendy Pasaribu} \\ Universitas Muhammadiyah Sumatera Utara Medan, Indonesia

\section{Syaiful Bahri} \\ Universitas Muhammadiyah Sumatera Utara Medan, Indonesia \\ syaifulbahri@umsu.ac.id
}

\begin{abstract}
The purpose of this study was to examine and analyze the influence of communication and workload on employee performance through job satisfaction at the Regional Representative Council Office of North Sumatra Province directly or indirectly. The approach used in this research is a causal approach. The population in this study were all state civil servants at the Regional Representative Council office of North Sumatra Province. The sample in this study used a sample of the Slovin formula totaling 52 state civil servants at the Regional Representative Council office of North Sumatra Province. Data collection techniques in this study used documentation, observation, and questionnaires. The data analysis technique in this study uses a quantitative approach using statistical analysis using the Auter Model Analysis test, Inner Model Analysis, and Hypothesis Testing. Processing data in this study using the PLS (Partial Least Square) software program. The results of this study prove that directly communication, workload and job satisfaction have a significant effect on employee performance and indirectly communication and workload have a significant effect on employee performance through job satisfaction at the Regional Representative Council office of North Sumatra Province.
\end{abstract}

Keywords Communication, Workload, Job Satisfaction and Performance

\section{PENDAHULUAN}

Dalam melaksanakan kerjanya, pegawai menghasilkan sesuatu yang disebut dengan kinerja. Kinerja merupakan hasil kerja seseorang pegawai selama periode tertentu dibandingkan dengan berbagai kemungkinan misalnya standard, target/sasaran atau kriteria yang telah ditentukan terlebih dahulu dan disepakati bersama. Kinerja adalah hasil kerja yang dapat dicapai oleh seseorang atau sekelompok orang dalam suatu organisasi, sesuai dengan wewenang dan tanggung jawab masing-masing, dalam rangka upaya mencapai tujuan organisasi bersangkutan secara legal, tidak melanggar hukum dan sesuai dengan norma dan etika (Muis et al., 2018). Kinerja merupakan suatu hasil kerja yang dicapai seseorang dalam melaksanakan tugas-tugas yang dibebankan kepadanya yang didasarkan atas kecakapan, pengalaman dan kesungguhan serta waktu. Kinerja ini adalah 
gabungan dari tiga faktor penting yaitu kemampuan dan minat seseorang pekerja, kemampuan dan penerimaan atas penjelasan delegasi tugas dan peran serta tingkat motivasi seorang pekerja (Muis et al., 2018).

Selain itu kinerja disamakan dengan hasil kerja seorang pegawai. Untuk mencapai kinerja yang baik, unsur yang paling dominan adalah sumber daya manusia, walaupun perencanaan telah tersusun dengan baik dan rapi tetapi apabila orang atau personil yang melaksanakan tidak berkualitas dan tidak memiliki semangat kerja yang tinggi, maka perencanaan yang telah disusun tersebut akan sia-sia (Arianty, 2015). Kinerja atau prestasi adalah hasil kerja secara kualitas dan kuantitas yang dicapai oleh seorang pegawai dalam melaksanakan tugasnya sesuai dengan tanggung jawab yang diberikan kepadanya. Salah satu jalan untuk mengatasi semua ini adalah dengan saluran komunikasi kesimulannya komunikasi yang baik dapat meningkatkan kepuasan pekerjaan yang nantinya akan mengoptimalkan kinerja karyawan sehingga tujuan perusahaan dapat tercapai (Ardiansyah, 2016). Selain komunikas yang mempengaruhi kinerja pegawai, beban kerja juga salah satu faktor yang sangat mempengaruhi kinerja pegawai tersebut. Beban kerja yang terlalu berlebihan akan dapat menimbulkan kelelahan (baik fisik maupun mental) dan reaksi-reaksi emosional seperti sakit kepala, gangguan pencernaan, dan mudah marah. Sedangkan beban kerja yang terlalu sedikit akan menimbulkan kebosanan dan rasa monoton. Kebosanan dalam kerja rutin sehari-hari karena tugas atau pekerjaan yang terlalu sedikit mengakibatkan kurangnya perhatian pada pekerjaan sehingga secara potensial juga membahayakan pekerja (Manuaba, 2000)

Selanjutnya faktor yang memengaruhi kinerja karyawan adalah kepuasan kerja. Kepuasan kerja merupakan salah satu faktor yang sangat penting untuk mendapatkan hasil kerja yang optimal. Ketika karyawan merasakan kepuasan dalam bekerja, maka ada upaya optimal untuk menyelesaikan tugas pekerjaannya dengan segenap kemampuan yang dimiliki. Hal ini lebih lanjut akan menunjang peningkatan produktivitas kerja yang diharapkan oleh perusahaan, (Wijayanti, 2014). Kepuasan kerja pada dasarnya merupakan sesuatu yang bersifat individual. Setiap individu memiliki tingkat kepuasan yang berbeda-beda sesuai dengan sistem nilai yang berlaku pada dirinya. Makin tinggi penilaian terhadap kegiatan dirasakan sesuai dengan keinginan individu, maka makin tinggi kepuasannya terhadap kegiatannya tersebut. Dengan demikian kepuasan merupakan evaluasi yang menggambarkan seseorang atas perasaan sikapnya senang atau tidak senang, puas atau tidak puas dalam bekerja, (V Rivai, 2014)

Kantor Dewan Perwakilan Rakyat Daerah Provinsi Sumatera Utara adalah salah satu instasi pemerintah yang membantu kegiatan anggota Dewan Perwakilan Rakyat Sumatera Utara yang tidak menghasilkan laba. Tugas Pokok adalah tugas yang paling pokok dari sebuah jabatan atau organisasi. Tugas Pokok memberi gambaran tentang ruang lingkup atau kompleksitas jabatan atau organisasi tersebut. Fungsi Kantor Dewan Perwakilan Rakyat Daerah Provinsi Sumatera Utara adalah perwujudan tugas kepemerintahan dibidang tertentu yang dilaksanakan dalam rangka mencapai tujuan pembangunan nasional. Definisi lain menyebutkan bahwa fungsi adalah sekelompok aktivitas yang tergolong pada jenis yang sama berdasarkan sifat atau pelaksanaannya. Suatu Organisasi menyelenggarakan fungsi - fungsi dalam rangka melaksanakan sebuah tugas pokok. Tugas Pokok dan Fungsi (Tupoksi) adalah sasaran utama atau pekerjaan yang dibebankan kepada organisasi untuk dicapai dan dilakukan.

Dalam setiap organisasi pemerintahan, tugas pokok dan fungsi merupakan bagian tidak terpisahkan dari keberadaan organisasi tersebut. Penetapan tugas pokok dan fungsi atas suatu unit organisasi menjadi landasan hukum unit organisasi tersebut beraktifitas 
sekaligus sebagai rambu-rambu dalam pelaksanaan tugas dan koordinasi pada tataran aplikasi di lapangan. Berdasarkan observasi penulis pada kantor Dewan Perwakilan Rakyat Daerah Provinsi Sumatera Utara dimana penulis menemukan beberapa permasalahan yaitu dimana masih rendahnya kinerja pegawai dalam melakukan pekerjaan dapat dilihat dari pegawai kurang mampu menyelesaikan pekerjaan tepat pada waktunya hal ini di sebabkan oleh kurang harmonisnya hubungan antar pegawai khususnya antar devisi dimana seringnya kesalah pahaman antar pegwai dalam melakukan pekerjaan. Selain itu fenomena yang terjadi pada pegawai kantor DPRD Sumut yaitu adanya penambahan aktifitas kerja yang mengakibatkan beban kerja makin tinggi seperti yang terjadi pada saat ini dengan maraknya wabah virus corona dimana beberapa pegawai memperoleh tambahan beban kerja dimana banyaknya perubahanperubahan masalah pekerjaan sehingga banyak pekerjaan yang ditambah yang di limpahkan kepada beberapa pegawai. Selain itu ada beberapa pegawai kurang puas dengan hasil pekerjaanya karena hasil pekerjaan yang dilakukan oleh pegawai seringkali tidak dinilai baik oleh pimpinan dan bebrapa devisi.

\section{LANDASAN TEORI \\ Kinerja}

Kinerja merupakan suatu hasil kerja yang dihasilkan oleh seorang karyawan diartikan untuk mencapai tujuan yang diharapkan. Selain itu kinerja seorang karyawan merupakan hal yang bersifat individual, karena setiap karyawan mempunyai tingkat kemampuan yang berbeda - beda dalam mengerjakan tugasnya. Pihak manajemen dapat mengukur karyawan atas hasil kerjanya berdasarkan kinerja dari masing - masing karyawan. Kinerja dan bukan merupakan hasil yang dapat dilihat pada saat itu juga.

Menurut (Mangkunegara, 2014) berpendapat bahwa kinerja karyawan adalah hasil kerja secara kualitas dan kuantitas yang dicapai oleh seseorang karyawan dalam melaksnakan tugasnya sesuai dengan tanggung jawab yang diberikan kepadanya. Menurut (Wibowo, 2010) menyatakan bahwa kinerja berasal darikata performance yang berarti hasil pekerjaan atau prestasi kerja. Namun perlu dipahami bahwa kinerja itu bukan sekedar hasil pekerjaan atau prestasi kerja, tetapi juga mencakup bagaimana proses pekerjaan itu berlangsung. Menurut (Veithzal Rivai, 2014) "kinerja merupakan penampilan hasil kerja pegawai baik secara kuantitas maupun mutu. Sedangka menurut (Darmadi, 2018) menyatakan bahwa kinerja pegawai dapat merupakan penampilan individu maupun kelompok kerja pegawai. Tiga hal penting dalam kinerja pegawai adalah tujuan, ukuran, dan penilaian.

Indikator kinerja merupakan sesuatu yang akan dihitung dan diukur. Adapun indikator kinerja (Mangkunegara, 2014) menyatakan yaitu :

1. Kualitas kerja

Kualitas kerja adalah mutu yang harus dihasilkan dalam pekerjaan.

2. Kuantitas kerja

Kuantitas kerja adalah jumlah yang harus diselesaikan dan dicapai dalam pekerjaan.

3. Dapat tidaknya diandalkan

Dapat tidaknya diandalkan merupakan apakah seseorang karyawan dapat mengikuti instruksi, memiliki inisiatif, hati-hati dan rajin dalam bekerja.

4. Sikap

Sikap yang dimiliki terhadap perusahaan, karyawan lain pekerjaan secara kerjasama. 


\section{Komunikasi}

Komunikasi adalah komunitas (community) yang juga menekankan kesamaan atau kebersamaan. Komunitas adalah sekelompok orang yang berkumpul atau hidup bersama untuk mencapai tujuan tertentu, dan mereka berbagi makna dan sikap. Tanpa komunikasi tidak akan ada komunitas. Komunitas bergantung pada pengalaman dan emosi bersama, dan komunikasi berperan dan menjelaskan kebersamaan itu. Oleh karena itu, komunitas juga berbagi bentuk-bentuk komunikasi yang berkaitan dengan seni, agama dan Bahasa (Mulyana, 2014). Pada dasarnya, komunikasi dilakukan secara verbal oleh dua belah pihak dilakukan lebih dari satu orang agar dapat dimengerti pesan yang disampaikan satu dengan yang lain. Tanpa adanya bahasa verbal antara kedua belah pihak (lebih dari satu orang), komunikasi satu dengan yang lain masih dapat dilakukan dengan cara menggerakkan tubuh dan menunjukan sikap tertentu, seperti menggerakkan kepala keatas dan kebawah, menunjuk sesuatu dengan tangan, melambaikan tangan, mengangkat bahu, dan tersenyum. Hal seperti ini disebut sebagai komunikasi nonverbal.

Komunikasi verbal adalah sarana utama untuk menyatakan pikiran, perasaan, dan maksud kita. Bahasa verbal merupakan kata-kata yang mempresentasikan berbagai aspek realitas individual kita (Mulyana, 2014) Komunikasi nonverbal adalah semua isyarat yang bukan kata-kata. Menurut (Samovar et al., 2010), komunikasi nonverbal mencakup semua rangsangan (kecuali rangsangan verbal) dalam suatu setting komunikasi, yang dihasilkan oleh individu dan penggunaan lingkungan individu, yang mempunyai nilai pesan potensial bagi pengirim atau penerima, jadi definisi ini mencakup perilaku yang disengaja juga tidak disengaja sebagai bagian dari peristiwa komunikasi secara keseluruhan, kita mengirim banyak pesan nonverbal tanpa disadari bahwa pesan-pesan tersebut bermakna bagi orang lain (Mulyana, 2014).

Menurut (Mangkunegara, 2014) indicator indikator komunikasi antara lain adalah :

1. Kemudahan dalam memperoleh informasi

Kinerja yang baik dari seseorang dapat tercipta apabila terdapat kemudahan dalam memperoleh informasi dalam suatu proses komunikasi maka terwujud kelancaran dalam pemindahan ide, gagasan maupun pengertian dari seseorang ke orang lain.

2. Intensitas komunikasi

Apabila banyaknya terjadi percakapan yang baik, maka proses komunikasi menjadi semakin lancar. Intensitas komunikasi sangat diperlukan guna kelancaran dalam proses komunikasi dalam suatu organisasi.

3. Efektivitas komunikasi

Efektivitas komunikasi mengandung pengertian bahwa komunikasi yang bersifat arus langsung, Artinya proses komunikasi yang dilakukan secara langsung dengan adanya frekuensi tatap muka untuk memudahkan orang lain mengetahui apa yang disampaikan komunikator.

4. Tingkat pemahaman pesan

Seseorang dapat memahami apa yang ingin disampaikan oleh seorang komunikator kepada penerima juga tergantung pada tingkat pemahaman seseorang. Adanya komunikasi yang baik dan lancar dapat lebih memudahkan seseorang atau penerima mengerti dan memahami pesan yang akan disampaikan.

5. Perubahan sikap

Setelah seseorang memahami pesan yang disampaikan oleh seorang komunikator kepada penerima pesan, maka akan terjadi perubahan sikap yang dilakukan sesuai dengan apa yang dikomunikasikan. 


\section{Beban Kerja}

Beban kerja adalah suatu jumlah pekerjaan yang diberikan kepada seseorang untuk diselesaikan dalam kurun waktu tertentu. Menurut (Tarwaka, 2014) menyimpulkan: "beban kerja merupakan suatu yang muncul dari interaksi antara tuntutan tugas, lingkungan kerja dimana digunakan sebagai tempat kerja, ketrampilan perilaku dan persepsi dari pekerjaan." Sedangkan menurut Permendagri Nomor 12 tahun 2008, beban kerja adalah besaran pekerjaan yang harus dipikul oleh suatu jabatan/unit organisasi dan merupakan hasil kali antara volume kerja dan norma waktu. Selanjutnya berdasarkan Undang - undang Kesehatan Nomor 36 tahun 2009 bahwa beban kerja adalah besaran pekerjaan yang harus dipikul oleh suatu jabatan/unit organisasi dan merupakan hasil antara jumlah pekerjaan dengan waktu. Setiap pekerja dapat bekerja secara sehat tanpa membahayakan dirinya sendiri maupun masyarakat di sekelilingnya, untuk itu perlu dilakukan upaya penyerasian antara kapasitas kerja, beban kerja dan lingkungan kerja sehingga diperoleh hasil kerja yang optimal.

Sedangkan Menurut (Moekijat, 2010) beban kerja adalah volume dari hasil kerja atau catatan tentang hasil pekerjaan yang dapat menunjukan volume yang dihasilkan oleh sejumlah pegawai dalam suatu bagian tertentu. Jumlah pekerjaan yang harus diselesaikan oleh sekelompok atau seseorang dalam waktu tertentu atau beban kerja dapat dilihat pada sudut pandang obyektif dan subyektif. Secara obyektif adalah keseluruhan waktu yang dipakai atau jumlah aktivitas yang dilakukan. Sedangkan beban kerja secara subyektif adalah ukuran yang dipakai seseorang terhadap pernyataan tentang perasaan kelebihan beban kerja, ukuran dari tekanan pekerjaan dan kepuasan kerja. Beban kerja sebagai sumber ketidakpuasan disebabkan oleh kelebihan beban kerja.

Menurut (Tarwaka, 2014) Beban kerja adalah "sekumpulan atau sejumlah kegiatan yang harus diselesaikan oleh suatu unit organisasi atau pemegang jaatan dalam jangka waktu tertentu." Beban kerja memuat 3 indikator, yaitu:

1. Beban waktu (time load), menunjukkan jumlah waktu yang tersedia dalam perencanaan, pelaksanaan dan monitoring tugas.

2. Beban usaha mental (mental effort load), yang berarti banyaknya usaha mental dalam melaksanakan suatu pekerjaan.

3. Beban tekanan psikologis (psychologis stress load) yang menunjukkan tingkat risiko pekerjaan, kebingungan dan frustasi.

\section{Kepuasan Kerja}

Setiap manusia mempunyai kebutuhan dalam hidupnya. Adanya keinginan untuk memenuhi kebutuhan itulah yang mendorong manusia melakukan berbagai aktivitas. Kebutuhan yang dimiliki manusia sangatlah beragam. Kepuasan seseorang antara satu dengan yang lainnya akan berbeda-beda. Jadi, kepuasan itu bersifat individual. Munurut (Handoko, 2013) "kepuasan kerja adalah keadaan emosional yang menyenangkan atau tidak menyenangkan dengan mana para karyawan memandang pekerjaan mereka". Selanjutnya menurut (Sutrisno, 2009) "kepuasan kerja karyawan merupakan masalah penting yang diperhatikan dalam hubungannya dengan produktivitas kerja karyawan dan ketidakpuasan sering dikaitkan dengan tingkat tuntutan dan keluhan pekerjaan yang tinggi. Pekerja dengan tingkat ketidakpuasan yang tinggi lebih mungkin untuk melakukan sabotase dan agresi yang pasif'. Sedangkan Menurut (Siagian, 2014) kepuasan kerja merupakan suatu cara pandang seseorang baik yang bersifat positif maupun yang bersifat negatif tentang pekerjaannya. 
Tolak ukur kepuasan kerja yang mutlak sulit untuk dicari karena setiap individu pegawai berbeda standar kepuasannya. Menurut (Veithzal Rivai, 2014) indikator dari kepuasan kerja terdiri dari:

1. Isi pekerjaan

Penampilan tugas atau atribut pekerjaan yang aktual dan sebagai kontrol terhadap pekerjaan. Karyawan akan merasa puas apabila tugas kerja dianggap menarik dan memberikan kesempatan belajar dan mendapat kepercayaan tanggung jawab atas pekerjaan itu.

2. Supervisi

Perhatian dan hubungan yang baik dari pimpinan kepada bawahan, sehingga karyawan akan merasa bahwa dirinya menjadi bagian yang penting dari organisasi. Sebaliknya, supervisi yang buruk dapat meningkatkan turn over dan absensi karyawan.

3. Organisasi dan manajemen

Perusahaan dan manajemen yang baik adalah yang mampu memberikan situasi dan kondisi kerja yang stabil, untuk memberikan kepuasan kepada karyawan.

4. Kesempatan untuk maju

Adanya kesempatan untuk memperoleh pengalaman dan peningkatan kemampuan selama bekerja akan memberikan kepuasan pada karyawan terhadap pekerjaannya.

5. Gaji dan keuntungan dalam bidang finansial

Gaji adalah suatu jumlah yang diterima dan keadaan yang dirasakan dari upah (gaji). Jika karyawan merasa bahwa gaji yang diperoleh mampu memenuhi kebutuhan hidupnya, diberikan secara adil didasrakan pada tingkat keterampilannya, tuntutan pekerjaan, serta standar gaji untuk pekerjaan tertentu, maka akan ada kepuasan kerja.

6. Rekan Kerja

Adanya hubungan yang dirasa saling mendukung dan saling memperhatikan antar rekan akan menciptakan lingkungan kerja yang nyaman dan hangat sehimgga menimbulkan kepuasan kerja pada karyawan.

7. Kondisi Kerja

Kondisi kerja yang mendukung akan meningkatkan kepuasan kerja pada karyawan. Kondisi kerja yang mendukung artinya tersedianya sarana dan prasarana kerja yang memadai sesuai dengan sifat tugas yang harus diselesaikannya.

\section{METODOLOGI PENELITIAN}

Jenis penelitian ini penelitian survey, dan penelitian kausal dengan menggunakan pendekatan kuantitatif. Populasi dalam penelitian ini adalah seluruh pegwai negeri sipil yang terdapat pada kantor Dewan Perwakilan Rakyat Daerah Provinsi Sumatera Utara yang berjumlah 110 orang. jumlah sampel dalam penelitian ini adalah sebanyak 52 orang aparatur sipil negara pada kantor Dewan Perwakilan Rakyat Daerah Provinsi Sumatera Utara. Pengambilan sampel ini menggunakan metode Nonprobability Sampling dengan menggunakan teknik Insidental sampling. Teknik pengumpulan data dalam penelitian ini menggunakan teknik dokumentasi, observasi, dan angket. Teknik analisis data dalam penelitian ini menggunakan pendekatan kuantitatif menggunakan analisis statistik dengan menggunkana uji Analisis Auter Model, Analisis Inner Model, dan Uji Hipotesis. Pengolahan data dalam penelitian ini menggunakan program software PLS (Partial Least Square). 


\section{HASIL PENELITIAN}

\section{Analisis Uji Outer Model}

Evaluasi terhadap model pengukuran indikator meliputi pemerikasaan individual item reliability, internal consistency atau composite reliability, average variance extracted, dan discriminant validity. Ketiga pengukuran pertama dikelompokan dalam convergent validity.

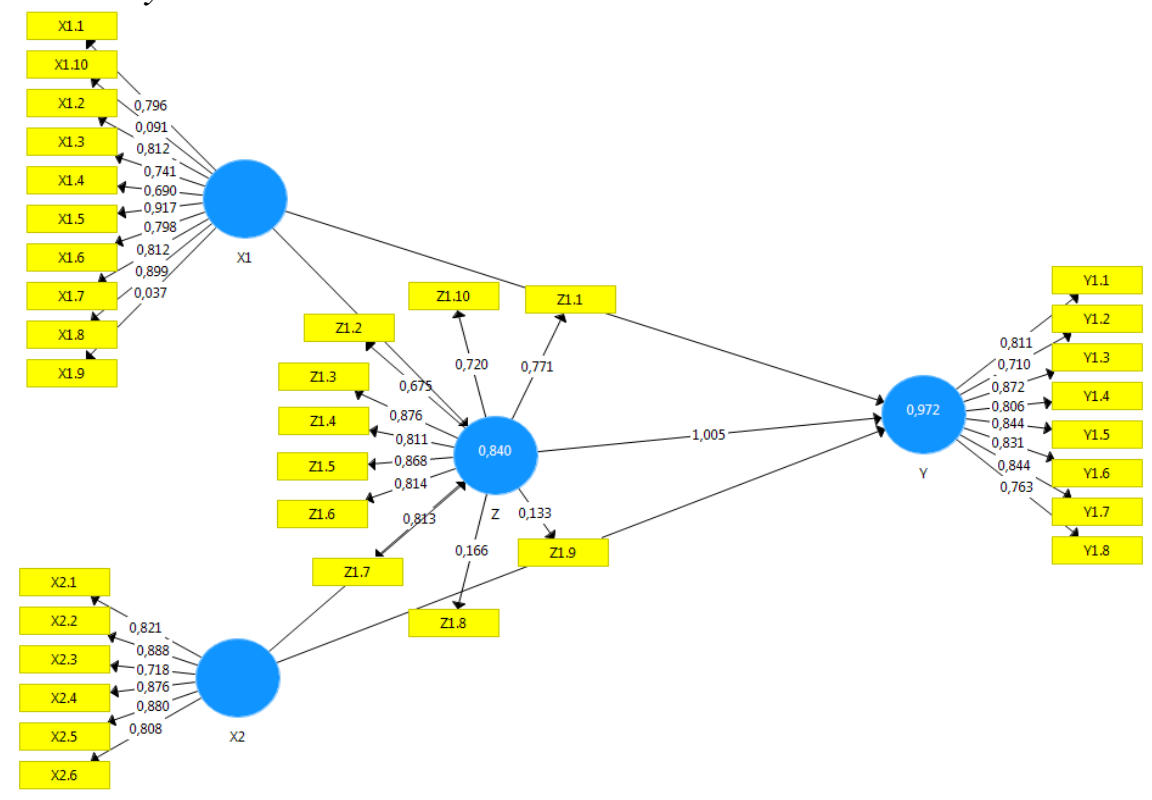

Gambar 1. Standardized Loading Factor Inner dan Outer Model

\section{Convergent Validity}

Convergent validity terdiri dari tiga pengujian yaitu reliability item (validitas tiap indikator), composite reability, dan average variance extracted (AVE). Convergent validity digunakan untuk mengukur seberapa besar indikator yang ada dapat menerangkan dimensi. Artinya semakin besar convergent validity maka semakin besar kemampuan dimensi tersebut dalam menerapkan variabel latennya. Validitas konvergen berhubungan dengan prinsip bahwa pengukur-pengukur (manifest variable) dari suatu konstruk seharusnya berkorelasi tinggi, validitas konvergen dinilai berdasarkan loading factor serta nilai Average Variance Extracted (AVE). Rule of thumb yang digunakan dalam uji validitas konvergen adalah nilai loading factor $>0,5$ serta nilai AVE $>0,5$ (Ghozali \& Latan, 2015). Hasil AVE disajikan pada Tabel 4.8 dan hasil outer loading pada Tabel 3.9 berikut ini:

Tabel 1. Hasil AVE (Average Variant Extracted)

\begin{tabular}{|c|r|c|}
\hline Variabel / Konstruk & \multicolumn{1}{c|}{ AVE } & Hasil Uji \\
\hline Komunikasi (X1) & 0.527 & Valid \\
\hline Beban kerja (X2) & 0.695 & Valid \\
\hline Kepuasan Kerja (Z) & 0.511 & Valid \\
\hline Kunerja (Y) & 0.659 & Valid \\
\hline
\end{tabular}

(Sumber : Data Diolah, 2021)

Berdasarkan tabel di atas diketahui bahwa nilai AVE setiap variabel adalah lebih besar dari 0,5. Sehingga dapat disimpulkan bahwa variabel atau konstruk yang digunakan adalah valid. 


\section{Discriminant Validity}

Pemeriksaan discriminant validity dari model pengukuran reflektif yang dinilai berdasarkan cross loading dan membandingkan antara nilai AVE dengan kuadrat korelasi antarkonstrak. Ukuran cross loading adalah adalah membandingkan korelasi indikator dengan konstraknya dan konstrak dari blok lain. Discriminant validity yang baik akan mampu menjelaskan variabel indikatornya lebih tinggi dibandingkan dengan menjelaskan varian dari indikator konstrak yang lain. Berikut adalah nilai discriminant validity untuk masing-masing indikator.

Tabel 2. Discriminant Validity

\begin{tabular}{|c|c|c|c|c|}
\hline Indikator & $\mathrm{X} 1$ & $\mathrm{X} 2$ & $\mathbf{Y}$ & $\mathbf{Z}$ \\
\hline X1.1 & 0.796 & 0.624 & 0.669 & 0.694 \\
\hline $\mathrm{X} 1.10$ & 0.091 & 0.039 & -0.008 & -0.013 \\
\hline $\mathrm{X} 1.2$ & 0.812 & 0.555 & 0.619 & 0.605 \\
\hline $\mathrm{X} 1.3$ & 0.741 & 0.556 & 0.715 & 0.631 \\
\hline X1.4 & 0.690 & 0.676 & 0.702 & 0.714 \\
\hline $\mathrm{X} 1.5$ & 0.917 & 0.822 & 0.818 & 0.824 \\
\hline X1.6 & 0.798 & 0.626 & 0.666 & 0.693 \\
\hline $\mathrm{X} 1.7$ & 0.812 & 0.555 & 0.619 & 0.605 \\
\hline $\mathrm{X} 1.8$ & 0.899 & 0.692 & 0.755 & 0.728 \\
\hline X1.9 & 0.037 & 0.013 & 0.047 & 0.054 \\
\hline $\mathrm{X} 2.1$ & 0.610 & 0.821 & 0.677 & 0.720 \\
\hline $\mathrm{X} 2.2$ & 0.632 & 0.888 & 0.710 & 0.764 \\
\hline$X 2.3$ & 0.597 & 0718 & 0.522 & 0.539 \\
\hline $\mathrm{X} 2.4$ & 0.749 & 0.876 & 0.825 & 0.828 \\
\hline $\mathrm{X} 2.5$ & 0.750 & 0.880 & 0725 & 0.741 \\
\hline $\mathrm{X} 2.6$ & 0.633 & 0.808 & 0.698 & 0.771 \\
\hline $\mathrm{Y} 1$ & 0.702 & 0.692 & 0811 & 0.814 \\
\hline Y2 & 0.747 & 0.561 & 0.710 & 0629 \\
\hline Y3 & 0.734 & 0.778 & 0.872 & 0.876 \\
\hline Y4 & 0.587 & 0.659 & 0806 & 0.811 \\
\hline Y5 & 0.668 & 0771 & 0.844 & 0.868 \\
\hline Y6 & 0.666 & 0.787 & 0.831 & 0.819 \\
\hline Y7 & 0.774 & 0.651 & 0.844 & 0813 \\
\hline Y8 & 0.762 & 0.523 & 0763 & 0.720 \\
\hline Z.1 & 0.633 & 0.808 & 0.698 & 0.771 \\
\hline Z.10 & 0.762 & 0.523 & 0.763 & 0.720 \\
\hline Z.2 & 0.547 & 0.753 & 0587 & 0.675 \\
\hline Z.3 & 0.734 & 0.778 & 0.872 & 0.876 \\
\hline Z.4 & 0.587 & 0.659 & 0.806 & 0.811 \\
\hline Z.5 & 0.668 & 0.771 & 0.844 & 0.868 \\
\hline Z.6 & 0.702 & 0.692 & 0.811 & 0.814 \\
\hline Z.7 & 0.774 & 0.651 & 0.844 & 0.813 \\
\hline Z.8 & 0.171 & 0.091 & 0.141 & 0.166 \\
\hline Z.9 & 0.201 & 0.056 & 0.140 & 0.133 \\
\hline
\end{tabular}

Berdasarkan sajian data pada tabel 2 di atas dapat diketahui bahwa masing-masing indikator pada variabel penelitian memiliki nilai cross loading lebih tinggi pada variabel yang dibentuknya dibandingkan dengan nilai cross loading pada variabel lainnya. 
Berdasarkan hasil yang diperoleh tersebut, dapat dinyatakan bahwa indikator-indikator yang digunakan dalam penelitian ini telah memiliki discriminant validity yang baik dalam menyusun variabelnya masing-masing.

\section{Composite Reliability}

Statistik yang digunakan dalam composite reliability atau reabilitas konstrak adalah cronbach's alpha dan D.G rho (PCA). Cronbach's alpha mengukur batas bawah nilai reliabilitas suatu konstruk sedangkan composite reliability mengukur nilai sesungguhnya reliabilitas suatu konstruk. Rule of thumb yang digunakan untuk nilai composite reliability lebih besar dari 0,6 serta nilai cronbach's alpha lebih besar dari 0,6. Dengan pengukuran tersebut apabila nilai yang dicapai adalah $>0,60$ maka dapat dikatakan bahwa konstruk tersebut memiliki reliabilitas yang tinggi. Hasil uji reabilitas kedua metode dapat dilihat pada tabel berikut ini :

Tabel 3. Hasil Uji Reabilitas

\begin{tabular}{|c|r|r|l|}
\hline Variabel / Konstruk & $\begin{array}{c}\text { Cronbach's } \\
\text { Alpha }\end{array}$ & $\begin{array}{c}\text { Composite } \\
\text { Reliability }\end{array}$ & Hasil Uji \\
\hline Komunikasi (X1) & $\mathbf{0 . 8 6 8}$ & 0,60 & Reliabel \\
\hline Beban kerja (X2) & $\mathbf{0 . 9 1 1}$ & 0,60 & Reliabel \\
\hline Kepuasan Kerja (Z) & $\mathbf{0 . 8 6 9}$ & 0,60 & Reliabel \\
\hline Kunerja (Y) & $\mathbf{0 . 9 2 5}$ & 0,60 & Reliabel \\
\hline
\end{tabular}

(Sumber : Data Diolah, 2021)

Berdasarkan sajian data pada tabel 3 di atas dapat diketahui bahwa masing-masing variabel penelitian memiliki nilai cronbach's alpha dan composite reliability $>0,60$. Berdasarkan hasil yang diperoleh tersebut, dapat dinyatakan bahwa variabel yang digunakan dalam penelitian dinyatakan reliabel.

\section{Analisis Inner Model}

\section{$\mathrm{Uji} \mathrm{F}^{2}$ ( Size Effect / F-Square)}

Berdasarkan pengolahan data yang telah dilakukan dengan menggunakan program smart PLS 3.0, diperoleh nilai $F$-Square yang dapat dilihat pada gambar dan tabel berikut:

Tabel 4. Nilai F-Square

\begin{tabular}{|c|c|}
\hline Variabel & F-Square \\
\hline Komunikasi $\rightarrow$ Kinerja & 0,535 \\
\hline Beban Kerja $\rightarrow$ Kinerja & 0,414 \\
\hline Kepuasan Kerja $\rightarrow$ Kinerja & 1,005 \\
\hline Komunikasi $\rightarrow$ Kepuasan Kerja & 0,419 \\
\hline Beban Kerja $\rightarrow$ Kepuasan Kerja & 0,548 \\
\hline Komunikasi $\rightarrow$ Kinerja melalui Kepuasan Kerja & 0,421 \\
\hline Beban Kerja $\rightarrow$ Kinerja melalui Kepuasan Kerja & 0,550 \\
\hline
\end{tabular}

Berdasarkan tabel 4. di atas diketahui bahwa :

1. Pengaruh komunikasi (X1) terhadap kinerja (Y) memiliki nilai $\mathrm{F}^{2}$ sebesar 0,535 mengindikasikan bahwa terdapat efek yang besar (baik).

2. Pengaruh beban kerja (X2) terhadap kinerja (Y) memiliki nilai $\mathrm{F}^{2}$ sebesar 0,414 mengindikasikan bahwa terdapat efek yang besar (baik).

3. Pengaruh kepuasan kerja (Z) terhadap kinerja (Y) memiliki nilai $\mathrm{F}^{2}$ sebesar 1,005 mengindikasikan bahwa terdapat efek yang besar (baik). 
4. Pengaruh komunikasi (X1) terhadap kepuasan kerja (Y) memiliki nilai $\mathrm{F}^{2}$ sebesar 0,419 mengindikasikan bahwa terdapat efek yang besar (baik).

5. Pengaruh beban kerja (X2) terhadap kepuasan kerja (Y) memiliki nilai $\mathrm{F}^{2}$ sebesar 0,548 mengindikasikan bahwa terdapat efek yang besar (baik).

6. Pengaruh komunikasi (X1) terhadap kinerja (Y) melalui kepusan kerja (Z) memiliki nilai $\mathrm{F}^{2}$ sebesar 0,421 mengindikasikan bahwa terdapat efek yang besar (baik).

7. Pengaruh beban kerja (X2) terhadap kinerja (Y) melalui kepusan kerja (Z)memiliki nilai $\mathrm{F}^{2}$ sebesar 0,550 mengindikasikan bahwa terdapat efek yang besar (baik).

\section{Uji Koefisien Determinasi (R-Square)}

Berdasarkan pengolahan data yang telah dilakukan dengan menggunakan program smartPLS 3.0, diperoleh nilai $R$-Square yang dapat dilihat pada gambar dan tabel berikut:

Tabel 5. Hasil Uji R-Square

\begin{tabular}{|l|ll|l|}
\hline & R Square & R Square Adjusted & \\
\hline Y & & 0.972 & 0.970 \\
\hline
\end{tabular}

\section{Sumber : PLS 3.00}

Dari tabel 5 di atas diketahui bahwa pengaruh X1, X2 dan Z terhadap Y dengan nilai r-square 0,972 mengindikasikan bahwa variasi nilai $Y$ mampu dijelaskan oleh variasi nilai X1, X2 dan Z sebesar 97,2\% atau dengan kata lain bahwa model tersebut adalah substansial (baik), dan 2,8\% dipengaruhi oleh variabel lain.

\section{Pengujian Hipotesis}

Pengujian ini adalah untuk menentukan koefisien jalur dari model struktural. Tujuannya adalah menguji signifikansi semua hubungan atau pengujian hipotesis. Pengujian hipotesis dalam penelitian ini dibagi menjadi pengaruh langsung dan pengaruh tidak langsung. Berdasarkan pengolahan data yang telah dilakukan dengan menggunakan program smartPLS 3.0, gambar hasil uji hipotesis pengaruh langsung dan tidak langsung dapat dilihat pada gambar path coefficient berikut ini :

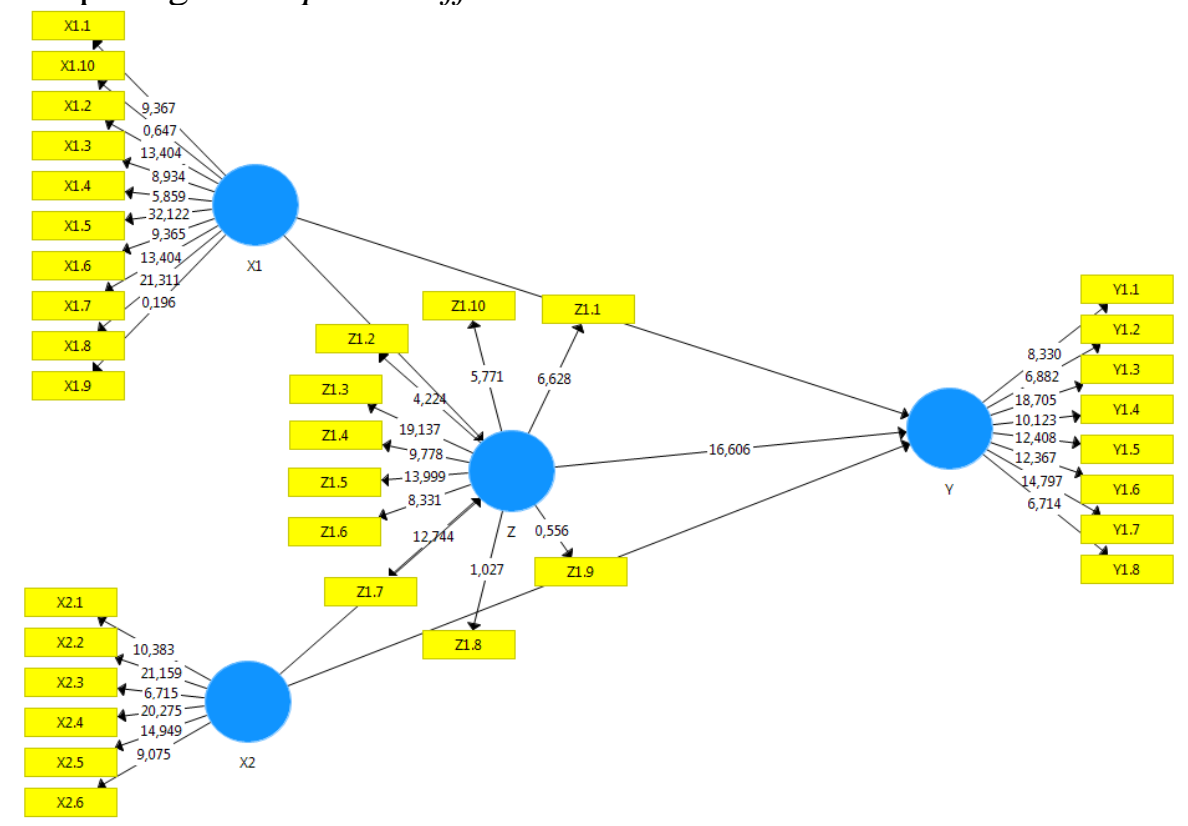

Gambar 2. Path Coefficient 


\section{Pengujian Hipotesis Pengaruh Langsung}

Hasil uji hipotesis pengaruh langsung dapat dilihat pada tabel path coefficient berikut ini :

Tabel 6. Path Coefficient

\begin{tabular}{|l|r|r|r|r|r|}
\hline & $\begin{array}{l}\text { Original } \\
\text { Sample (O) }\end{array}$ & $\begin{array}{l}\text { Sample } \\
\text { Mean (M) }\end{array}$ & $\begin{array}{l}\text { Standard Error } \\
\text { (STERR) }\end{array}$ & $\begin{array}{l}\text { T Statistics } \\
(\mid \text { O/STERR })\end{array}$ & $\begin{array}{l}\text { P } \\
\text { Values }\end{array}$ \\
\hline X1 -> Y & 0,114 & 0,103 & 0,060 & 1,968 & $\mathbf{0 . 0 4 7}$ \\
\hline $\mathbf{X 1}$-> Z & 0,419 & 0,450 & 0,107 & 3,895 & $\mathbf{0 . 0 0 0}$ \\
\hline X2 -> Y & $-0,137$ & $-0,119$ & 0,065 & 2,113 & $\mathbf{0 . 0 3 5}$ \\
\hline X2 -> Z & 0,548 & 0,510 & 0,124 & 4,423 & $\mathbf{0 . 0 0 0}$ \\
\hline $\mathbf{Z}$-> Y & 1,005 & 0,997 & 0,061 & 16,606 & $\mathbf{0 . 0 0 0}$ \\
\hline
\end{tabular}

\section{Sumber : PLS 3.00}

Berdasarkan Tabel 6 di atas, dapat dinyatakan bahwa pengujian hipotesis adalah sebagai berikut:

1. Pengaruh komunikasi terhadap kinerja mempunyai koefisien jalur sebesar 0,144. Ini menunjukkan bahwa jika semakin baik komunikasi antar pegawai maupun dengan pimpinan, maka semakin tinggi kinerja pegawai pada kantor Dewan Perwakilan Rakyat Daerah Provinsi Sumatera Utara. Pengaruh tersebut mempunyai nilai probabilitas (p-values) sebesar $0,047<0,05$, berarti komunikasi berpengaruh signifikan terhadap kinerja pegawai pada kantor Dewan Perwakilan Rakyat Daerah Provinsi Sumatera Utara.

2. Pengaruh komunikasi terhadap kepuasan kerja mempunyai koefisien jalur sebesar 0,419. Ini menunjukkan bahwa jika semakin baik komunikasi antar pegawai maupun dengan pimpinan, maka semakin tinggi kepuasan kerja pegawai pada kantor Dewan Perwakilan Rakyat Daerah Provinsi Sumatera Utara. Pengaruh tersebut mempunyai nilai probabilitas ( $\mathrm{p}$-values) sebesar $0,000<0,05$, berarti komunikasi berpengaruh signifikan terhadap kepuasan kerja pegawai pada kantor Dewan Perwakilan Rakyat Daerah Provinsi Sumatera Utara.

3. Pengaruh beban kerja terhadap kinerja mempunyai koefisien jalur sebesar -0,137. Ini menunjukkan bahwa jika penambahan beban kerja pegawai sesuai dengan kemampuan pegawai, maka semakin tinggi kinerja pegawai pada kantor Dewan Perwakilan Rakyat Daerah Provinsi Sumatera Utara. Pengaruh tersebut mempunyai nilai probabilitas (pvalues) sebesar $0,035<0,05$, berarti baban kerja berpengaruh signifikan terhadap kinerja pegawai pada kantor Dewan Perwakilan Rakyat Daerah Provinsi Sumatera Utara.

4. Pengaruh beban kerja terhadap kepuasan kerja mempunyai koefisien jalur sebesar 0,548 . Ini menunjukkan bahwa jika penambahan beban kerja pegawai sesuai dengan kemampuan pegawai, maka semakin tinggi kepuasan kerja pegawai pada kantor Dewan Perwakilan Rakyat Daerah Provinsi Sumatera Utara. Pengaruh tersebut mempunyai nilai probabilitas ( $\mathrm{p}$-values) sebesar $0,000<0,05$, berarti beban kerja berpengaruh signifikan terhadap kepuasan kerja pegawai pada kantor Dewan Perwakilan Rakyat Daerah Provinsi Sumatera Utara.

5. Pengaruh kepuasan kerja terhadap kinerja mempunyai koefisien jalur sebesar $-1,005$. Ini menunjukkan bahwa jika pegawai merasa puas, maka semakin tinggi kinerja pegawai pada kantor Dewan Perwakilan Rakyat Daerah Provinsi Sumatera Utara. Pengaruh tersebut mempunyai nilai probabilitas (p-values) sebesar $0,000<0,05$, berarti kepuasan kerja berpengaruh signifikan terhadap kinerja pegawai pada kantor Dewan Perwakilan Rakyat Daerah Provinsi Sumatera Utara. 


\section{Pengujian Seacar Tidak Langsung}

Adapun pengaruh tidak langsung diantara variabel bebas dan variabel terikat pada penelitian ini dapat dikemukakan adalah sebagai berikut :

Tabel 7. Specific Indirect Effects

\begin{tabular}{|l|r|r|r|r|r|}
\hline & $\begin{array}{l}\text { Original } \\
\text { Sample (O) }\end{array}$ & $\begin{array}{l}\text { Sample } \\
\text { Mean } \\
(\mathbf{M})\end{array}$ & $\begin{array}{l}\text { Standard } \\
\text { Deviation } \\
\text { (STDEV) }\end{array}$ & $\begin{array}{l}\text { T Statistics } \\
(\mid \mathbf{O} / \text { STDEV|) }\end{array}$ & P Values \\
\hline $\mathbf{X 1 ~}>\mathbf{Z}$-> Y & 0.421 & 0.450 & 0.116 & 3,519 & $\mathbf{0 . 0 0 0}$ \\
\hline $\mathbf{X 2}->\mathbf{Z}->$ Y & 0.550 & 0.508 & 0.124 & 4,162 & $\mathbf{0 . 0 0 0}$ \\
\hline
\end{tabular}

\section{Sumber : PLS 3.00}

Berdasarkan Tabel 7 di atas, dapat dinyatakan bahwa pengujian hipotesis adalah sebagai berikut:

1. Pengaruh komunikasi terhadap kinerja melalui kepuasan kerja mempunyai koefisien jalur sebesar 0,421. Pengaruh tersebut mempunyai nilai probabilitas ( $\mathrm{p}$-values) sebesar $0,000<0,05$, berarti dapat disimpulkan bahwa komunikasi berpengaruh signifikan terhadap kinerja pegawai melalui kepuasan kerja pegawai pada kantor Dewan Perwakilan Rakyat Daerah Provinsi Sumatera Utara.

2. Pengaruh beban kerja terhadap kinerja melalui kepuasan kerja mempunyai koefisien jalur sebesar 0,550. Pengaruh tersebut mempunyai nilai probabilitas ( $\mathrm{p}$-values) sebesar $0,000<0,05$, berarti dapat disimpulkan bahwa beban kerja berpengaruh signifikan terhadap kinerja pegawai melalui kepuasan kerja pegawai pada kantor Dewan Perwakilan Rakyat Daerah Provinsi Sumatera Utara.

\section{Pembahasan}

Hasil temuan dalam penelitian ini adalah mengenai hasil temuan penelitian ini terhadap kesesuaian teori, pendapat maupun penelitian terdahulu yang telah dikemukakan hasil penelitian sebelumnya serta pola perilaku yang harus dilakukan untuk mengatasi hal-hal tersebut. Berikut ini ada tujuh bagian utama yang akan dibahas dalam analisis hasil temuan penelitian ini, yaitu sebagai berikut:

\section{Pengaruh Komunikasi Terhadap Kinerja}

Dari hasil analisis pengujian hipotesis diketahui bahwa komunikasi berpengaruh signifikan terhadap kinerja yang dinilai dengan koefisien jalur sebesar 0,114. Nilai probabilitas yang didapatkan adalah sebesar 0,047 <0,05, dengan nilai thitung sebesar 1,97, dan nilai $t_{\text {tabel }} 1.96$, dengan demikian $t_{\text {hitung }}$ lebih besar dari $t_{\text {tabel }}(1,97>1.96)$ sehingga H0 ditolak (Ha diterima). Hal ini berarti komunikasi berpengaruh signifikan terhadap kinerja pegawai pada kantor Dewan Perwakilan Rakyat Daerah Provinsi Sumatera Utara. Hal ini menunjukkan bahwa dengan jalinan komunikasi yang baik antar pegawai maupun dengan pimpinan maka kinerja pegawai pada kantor Dewan Perwakilan Rakyat Daerah Provinsi Sumatera Utara semakin meningkat, dimana dengan keefektifan komunikasi maka pegawai dapat mengerti pesan-pesan tentang pekerjaan. Keefektifan komunikasi berjalan dengan baik maka pegawai memahami maksud dari informasi komunikasi tersebut selain itu komunikasi antar atasan kepada bawahan memiliki kemaknaan yang saling dimengerti satu sama lainnya agar terjadi harmonisasi komunikasi organisasi begitupun dengan sebaliknya. Komunikasi yang terjadi akan mempengaruhi kegiatan organisasi, seperti efisiensi kerja, efektivitas kerja, kinerja pegawai dan organisasi. Hasil penelitian ini sejalan dengan hasil penelitian terdahulu yang dilakukan oleh (Wandi et al., 2019) (Ardiansyah, 2016) menyimpulkan bahwa komunikas berpengaruh signifikan terhadap kinerja. 


\section{Pengaruh Beban Kerja Terhadap Kinerja}

Dari hasil analisis pengujian hipotesis diketahui bahwa beban kerja berpengaruh signifikan terhadap kinerja yang dinilai dengan koefisien jalur sebesar -0,137. Nilai probabilitas yang didapatkan adalah sebesar $0,035<0,05$, dengan nilai thitung sebesar 2,113 , dan nilai $t_{\text {tabel }} 1.96$, dengan demikian $t_{\text {hitung }}$ lebih besar dari $t_{\text {tabel }}(2,113>1.96)$ sehingga H0 ditolak (Ha diterima). Hal ini berarti beban kerja berpengaruh signifikan terhadap kinerja pegawai pada kantor Dewan Perwakilan Rakyat Daerah Provinsi Sumatera Utara. Hal ini menunjukkan bahwa dengan penambahan beban kerja yang sesuai dengan kemapuan pegawai maka kinerja pegawai kantor Dewan Perwakilan Rakyat Daerah Provinsi Sumatera Utara akan semakin meningkat, dimana dengan penambahan beban kerja yang sesuai dengan kemampuan pegawai maka pegawai tersebut akan lebih sungguh-sungguh dalam melakukan pekerjaan serta memanfaatkan waktu kerjanya untuk menyelesaikan pekerjaan sehingga kinerja pegawai akan semakin meningkat. Hasil penelitian ini sejalan dengan hasil penelitian terdahulu yang dilakukan oleh (Rolos et al., 2018) dan (Chandra \& Adriansyah, 2017) menyimpulkan bahwa beban kerja berpengaruh signifikan terhadap kinerja.

\section{Pengaruh Kepuasan Kerja Terhadap Kinerja}

Dari hasil analisis pengujian hipotesis diketahui bahwa kepuasan kerja berpengaruh signifikan terhadap kinerja yang dinilai dengan koefisien jalur sebesar 1,005. Nilai probabilitas yang didapatkan adalah sebesar $0,000<0,05$, dengan nilai thitung sebesar 16,606, dan nilai tabel 1.96, dengan demikian $t_{\text {hitung }}$ lebih besar dari $t_{\text {tabel }}$ (16,606>1.96) sehingga H0 ditolak (Ha diterima). Hal ini berarti kepuasan kerja berpengaruh signifikan terhadap kinerja pegawai pada kantor Dewan Perwakilan Rakyat Daerah Provinsi Sumatera Utara. Hal ini menjukkan bahwa dengan kepuasan kerja yang dimiliki pegawai yang semakin meningkat maka kinerja pegawai pada kantor Dewan Perwakilan Rakyat Daerah Provinsi Sumatera Utara akan semakin meningkat, dimana dengan kepuasan kerja yang dimiliki pegawai, pegawai puas atas apa yang pegawai terima serta hubungan dengan pimpinan maka pegawai akan lebih sungguh-sungguh dalam melakukan pekerjaanya sehinga kinerja pegawai tersebut akan semakin meningkat. Hasil penelitian ini sejalan dengan hasil penelitian terdahulu yang dilakukan oleh (Kristianto, 2011), (Adhan et al., 2020), (Sembiring et al., 2021), (Syahputra \& Jufrizen, 2019), (Jufrizen, 2017), (Jufrizen \& Sitorus, 2021) dan (Jufrizen et al., 2017) yang menyimpulkan bahwa kepuasan kerja berpengaruh terhadap kinerja karyawan.

\section{Pengaruh Komunikasi Terhadap Kepuasan Kerja}

Dari hasil analisis pengujian hipotesis diketahui bahwa komunikasi berpengaruh signifikan terhadap kepuasan kerja yang dinilai dengan koefisien jalur sebesar 0,419. Nilai probabilitas yang didapatkan adalah sebesar $0,000<0,05$, dengan nilai thitung sebesar 3,895 , dan nilai $t_{\text {tabel }} 1.96$, dengan demikian $t_{\text {hitung }}$ lebih besar dari $t_{\text {tabel }}(3,895>1.96)$ sehingga $\mathrm{HO}$ ditolak (Ha diterima). Hal ini berarti komunikasi berpengaruh signifikan terhadap kepuasan kerja pada kantor Dewan Perwakilan Rakyat Daerah Provinsi Sumatera Utara. Hail ini menunjukkan bahwa dengan keefektifan komunikasi pegawai maka kepuasan kerja pegawai pada kantor Dewan Perwakilan Rakyat Daerah Provinsi Sumatera Utara akan semakin meningkat, dimana dengan jalinan komunikasi pegawai dengan pimimpinan dan pegawai dengan pegawai maka suasana kerja pegawai akan semakin harmonis, dengan keharmonisan lingkungan kerja pegawai akan merasa nyaman dengan lingkungan tersebut sehingga kepuasan kerja pegawai tersebut akan semakin meningkat. Hasil penelitian ini sejalan dengan hasil penelitian yang dilakukan oleh 
(Wirawan \& Sudharma, 2015) dan (Dwijayanti, 2013) menyimpulkan bahwa komunikasi berpengaruh signifikan terhadap kepuasan kerja.

\section{Pengaruh Beban Kerja Terhadap Kepuasan Kerja}

Dari hasil analisis pengujian hipotesis diketahui bahwa beban kerja berpengaruh signifikan terhadap kepuasan kerja yang dinilai dengan koefisien jalur sebesar 0,548. Nilai probabilitas yang didapatkan adalah sebesar $0,000<0,05$, dengan nilai thitung sebesar 4,423 , dan nilai $t_{\text {tabel }} 1.96$, dengan demikian $t_{\text {hitung }}$ lebih besar dari $t_{\text {tabel }}(4,423>1.96)$ sehingga $\mathrm{HO}$ ditolak (Ha diterima). Hal ini berarti beban kerja berpengaruh signifikan terhadap kepuasan kerja pada kantor Dewan Perwakilan Rakyat Daerah Provinsi Sumatera Utara. Hal ini menunjukkan bahwa dengan penambahan beban kerja yang sesuai dengan kemampuan pegawai maka kepuasan kerja pegawai pada kantor Dewan Perwakilan Rakyat Daerah Provinsi Sumatera Utara akan semakin meningkat. Dimana dengan penambahan beban kerja pegawai tersebut akan lebih sunguh-sungguh dan dapat memanfaatkan waktu kerjanya dengan baik sehingga kinerja pegawai tersebut akan semakin tinggi, dengan semakin tingginya kinerja pegawai maka kepuasan kerja pegawai akan semakin meningkat. Hasil penelitian ini sejalan dengan hasil penelitian terdahulu yang dilakukan oleh (Wijayanti, 2014) menyimpilkan bahwa beban kerja berpengaruh signifikan terhadap kepuasan kerja.

\section{Pengaruh Komunikasi Terhadap Kinerja Melalui Kepuasan Kerja}

Dari hasil analisis pengujian hipotesis diketahui bahwa komunikasi berpengaruh signifikan terhadap kinerja melalui kepuasan kerja yang dinilai dengan koefisien jalur sebesar 0,421 . Nilai probabilitas yang didapatkan adalah sebesar $0,000<0,05$, dengan nilai $t_{\text {hitung }}$ sebesar 3,638, dan nilai $t_{\text {tabel }} 1.96$, dengan demikian $t_{\text {hitung }}$ lebih besar dari $t_{\text {tabel }}(3,638>1.96)$ sehingga H0 ditolak (Ha diterima). Hal ini berarti komunikasi berpengaruh signifikan terhadap kinerja melalui kepuasan kerja pada kantor Dewan Perwakilan Rakyat Daerah Provinsi Sumatera Utara. Hal ini menunjukkan bahwa dengan komunikasi yang efektif maka kepuasan kerja pegawai akan semakin meningkat dengan demikian maka kinerja pegawai pada kantor Dewan Perwakilan Rakyat Daerah Provinsi Sumatera Utara akan semakin meningkat, dimana dengan keefektifan komunikasi maka pegawai dapat mengerti pesan-pesan tentang pekerjaan selain itu keefektifan komunikasi berjalan dengan baik maka pegawai memahami maksud dari informasi komunikasi tersebut selain itu komunikasi antar atasan kepada bawahan memiliki kemaknaan yang saling dimengerti satu sama lainnya agar terjadi harmonisasi komunikasi organisasi begitupun dengan sebaliknya sehingga pegawai akan merasa puas atas hubungan tersebut, dengan demikian maka pegawai akan lebih semangat dalam melakukan pekerjaan sehingga kinerja pegawai akan semakin meningkat.

\section{Pengaruh Beban Kerja Terhadap Kinerja Melalui Kepuasan Kerja}

Dari hasil analisis pengujian hipotesis diketahui bahwa beban kerja berpengaruh signifikan terhadap kinerja melalui kepuasan kerja yang dinilai dengan koefisien jalur sebesar 0,550. Nilai probabilitas yang didapatkan adalah sebesar $0,000<0,05$, dengan nilai thitung sebesar 4,453, dan nilai $t_{\text {tabel }} 1.96$, dengan demikian $t_{\text {hitung }}$ lebih besar dari $t_{\text {tabel }}(4,453>1.96)$ sehingga $\mathrm{H} 0$ ditolak (Ha diterima). Hal ini berarti beban kerja berpengaruh signifikan terhadap kinerja melalui kepuasan kerja pada kantor Dewan Perwakilan Rakyat Daerah Provinsi Sumatera Utara. Hal ini menunjukkan bahwa dengan beban kerja yang diberikan yang sesuai dengan kemampuan pegawai maka pegawai tersebut akan semakin puas sehingga kinerja pegawai pada kantor Dewan Perwakilan Rakyat Daerah Provinsi Sumatera Utara akan semakin meningkat, dimana dengan penambahan beban kerja pegawai tersebut akan lebih sunguh-sungguh dan dapat 
memanfaatkan waktu kerjanya dengan baik sehingga kinerja pegawai tersebut akan semakin tinggi, dengan semakin tingginya kepuasan kerja pegawai maka pegawai tersebut akan sungguh-sungguh dalam melaksanakan pekerjkaanya dengan demikian maka kinerja pegawai akan semakin meningkat.

\section{KESIMPULAN}

Kesimpulan dari penelitian mengenai Pengaruh Komunikasi Dan Beban Kerja Terhadap Kinerja Pegawai Melalui Kepuasan Kerja Pegawai Pada Kantor Dewan Perwakilan Rakyat Daerah Provinsi Sumatera Utara adalah sebagai berikut. Secara langsung komunikasi berpengaruh signifikan terhadap kinerja pegawai pada kantor Dewan Perwakilan Rakyat Daerah Provinsi Sumatera Utara. Secara langsung beban kerja berpengaruh signifikan terhadap kinerja pegawai pada kantor Dewan Perwakilan Rakyat Daerah Provinsi Sumatera Utara. Secara langsung kepuasan kerja berpengaruh signifikan terhadap kinerja pegawai pada kantor Dewan Perwakilan Rakyat Daerah Provinsi Sumatera Utara. Secara langsung komunikasi berpengaruh signifikan terhadap kepuasan kerja pegawai pada kantor Dewan Perwakilan Rakyat Daerah Provinsi Sumatera Utara. Secara langsung beban kerja berpengaruh signifikan terhadap kepuasan kerja pegawai pada kantor Dewan Perwakilan Rakyat Daerah Provinsi Sumatera Utara. Secara tidak langsung komunikasi berpengaruh signifikan terhadap kinerja pegawai melalui kepuasan kerja pegawai pada kantor Dewan Perwakilan Rakyat Daerah Provinsi Sumatera Utara dan secara tidak langsung beban kerja berpengaruh signifikan terhadap kinerja pegawai melalui kepuasan kerja pegawai pada kantor Dewan Perwakilan Rakyat Daerah Provinsi Sumatera Utara.

\section{DAFTAR PUSTAKA}

Adhan, M., Jufrizen, J., Prayogi, M. A., \& Siswadi, Y. (2020). Peran Mediasi Komitmen Organisasi pada Pengaruh Kepuasan Kerja terhadap Kinerja Dosen Tetap Universitas Swasta di Kota Medan. Jurnal Samudra Ekonomi Dan Bisnis, 11(1), 115. https://doi.org/10.33059/jseb.v11i1.1654

Ardiansyah, D. O. (2016). Pengaruh Komunikasi Terhadap Kinerja Karyawan Dengan Dimediasi Oleh Kepuasan Kerja. Jurnal Bisnis Dan Manajemen, 3(1), 16-30.

Arianty, N. (2015). Pengaruh Pelimpahan Wewenang dan Koordinasi Kerja Terhadap Pengambilan Keputusan di Perusahaan Asuransi Di Kota Medan. Jurnal Manajemen Tools, 4(2), 80-91.

Chandra, R., \& Adriansyah, D. (2017). Pengaruh Beban Kerja dan Stres Kerja terhadap Kinerja Karyawan pada PT. Mega Auto Central Finance Cabang di Langsa. Jurnal Manajemen Dan Keuangan, 6(1), 670-678.

Darmadi. (2018). Manajemen Sumber Daya Manusia. CV. Budi Utama.

Dwijayanti, K. D. (2013). Pengaruh Kompensasi Finansial Komunikasi dan Lingkungan Kerja Fisik Terhadap Kepuasan Kerja Karyawan Pada Bakungsari Hotel Di Kuta Badung. Jurnal Manajemen Dan Bisnis, 1(1), 44-56.

Handoko, H. (2000). Manajemen Personalia. BPFE.

Jufrizen, J. (2017). Pengaruh Kepemimpinan dan Budaya Organisasi Terhadap Kinerja dengan Kepuasan Kerja sebagai Variabel Intervening. Jurnal Ilmiah Kohesi, 1(1), $166-177$.

Jufrizen, J., Lumbanraja, P., Salim, S. R. A., \& Gultom, P. (2017). The Effect of Compensation, Organizational Culture and Islamic Work Ethic Towards the Job Satisfaction and the Impact on the Permanent Lecturers. International Business 
Management, 11(1), 53-60.

Jufrizen, J., \& Sitorus, T. S. (2021). Pengaruh Motivasi Kerja dan Kepuasan Kerja Terhadap Kinerja Dengan Disiplin Kerja Sebagai Variabel Intervening. Prosiding Seminar Nasional Teknologi Edukasi Sosial Dan Humaniora, 1(1), 841-856. https://doi.org/10.53695/sintesa.v1i1.419

Kristianto, D. (2011). Pengaruh Kepuasan Kerja Terhadap Kinerja Karyawan Dengan Komitmen Organisasional Sebagai Variabel Intervening (Studi pada RSUD Tugurejo Semarang). Jurnal Bisnis Strategi, 20(2), 31-43.

Mangkunegara, A. A. (2014). Evaluasi Kinerja Sumber Daya Manusia. Refika Aditama. Manuaba. (2000). Hubungan Beban Kerja dan Kapasitas Kerja. Rinekal.

Moekijat. (2010). Manajemen Sumber Daya Manusia. Mandar Maju.

Muis, M. R., Jufrizen, J., \& Fahmi, M. (2018). Pengaruh Budaya Organisasi Dan Komitmen Organisasi Terhadap Kinerja Karyawan. Jesya (Jurnal Ekonomi \& Ekonomi Syariah), 1(1), 9-25.

Mulyana, D. (2014). Ilmu Komunikasi: Suatu Pengantar. PT. Remaja Rosdakarya.

Rivai, V. (2014). Manajemen Sumber Daya Manusia Untuk Perusahaan. PT. Raja Grafindo Persada.

Rivai, Veithzal. (2014). Manajemen Sumber Daya Manusia Untuk Perusahaan (6th ed.). PT. Raja Grafindo Persada.

Rolos, J. K. R., Sambul, S. A. P., \& Rumawa, W. (2018). Pengaruh Beban Kerja Terhadap Kinerja Karyawan Pada PT. Asuransi Jiwasraya Cabang Manado Kota. Jurnal Administrasi Bisnis, 6(4), 19-27.

Samovar, L. A., Edwin, R. M. D., \& Richard, E. P. (2010). Intercultural Communication A Reader. Wadsworth.

Sembiring, M., Jufrizen, J., \& Tanjung, H. (2021). Efek Mediasi Kepuasan Kerja pada Pengaruh Motivasi Dan Kemampuan Kerja Terhadap Kinerja Pegawai. Maneggio: Junal Ilmiah Magister Manajemen, 4(1), 130-143. https://doi.org/10.30596/maneggio.v4i1.6775

Siagian, S. P. (2014). Manajemen dan Evaluasi Kinerja. Bumi Aksara.

Sutrisno, E. (2009). Manajemen Sumber Daya Manusia. Prenadamedia Group.

Syahputra, I., \& Jufrizen, J. (2019). Pengaruh Diklat, Promosi, Dan Kepuasan Kerja Terhadap Kinerja Pegawai. Maneggio: Jurnal Ilmiah Magister Manajemen, 2(1), 104-116. https://doi.org/10.30596/maneggio.v2i1.3364

Tarwaka. (2014). Ergonomi Industri; Dasar-dasar Pengetahuan Ergonomi dan Aplikasi di Tempat Kerja. Harapan Press.

Wandi, D., Adha, S., \& Asriyah, I. (2019). Pengaruh Komunikasi Terhadap Kinerja Pegawai Pada Badan Penanggulangan Bencana Daerah (BPBD) Provinsi Banten. Jurnal Ekonomi Vokasi, 2(2), 18-30, ISSN:1098-6596.

Wibowo, W. (2010). Manajemen Kinerja. Rajawali Pres.

Wijayanti. (2014). Pengaruh Dukungan Organisasi dan Efikasi Diri Terhadap Kepuasan Melalui Komitemen Organisasi. Jurnal Bisnis Dan Manajemen, 6(2), 77-88.

Wirawan, I. D. G. K., \& Sudharma, I. N. (2015). Pengaruh Komunikasi, Motivasi dan Lingkungan Kerja Fisik Terhadap Kepuasan Kerja Pegawai Sekretariat Daerah Kota Denpasar. E-Jurnal Manajemen Unud, 4(10), 3037-3062. 